$\Leftrightarrow \quad$ LUST ON TRIAL $\Longleftrightarrow$ 



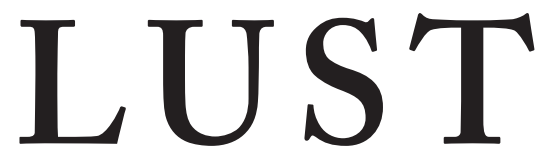

\title{
ON TRIAL
}

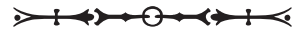 \\ CENSORSHIP \\ AND THE RISE OF \\ AMERICAN OBSCENITY \\ IN THE AGE OF \\ ANTHONY COMSTOCK

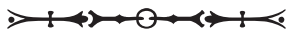

AMY WERBEL

COLUMBIA

UNIVERSITY

PRESS

NEW YORK 


$$
\begin{aligned}
& \text { Columbia University Press } \\
& \text { Publishers Since } 1893 \\
& \text { New York Chichester, West Sussex } \\
& \text { cup.columbia.edu } \\
& \text { Copyright (C) 2018 Columbia University Press } \\
& \text { All rights reserved } \\
& \text { Library of Congress Cataloging-in-Publication Data } \\
& \text { Names: Werbel, Amy Beth, author. }
\end{aligned}
$$

Title: Lust on trial : censorship and the rise of American obscenity in the age of Anthony Comstock / Amy Werbel.

Description: New York : Columbia University Press, 2018. | Includes bibliographical references and index.

Identifiers: LCCN 20I704244I (print) | LCCN 2017049977 (e-book) |

ISBN 978023154703I (e-book) | ISBN 9780231175227 (cloth: alk paper) Subjects: LCSH: Comstock, Anthony, 1844-1915. | New York Society for the Suppression of Vice. | Censorship-United States-History. | Obscenity (Law) -

United States-History. | United States-Moral conditions.

Classification: LCC HV6705 (e-book) | LCC HV6705 W47 2018 (print) |

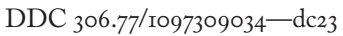

LC record available at https://1ccn.loc.gov/201704244I

Columbia University Press books are printed on permanent and durable acid-free paper.

Printed in the United States of America

Cover design: Philip Pascuzzo

Cover image: Bernarr Macfadden's Women's Physical Culture Competition, 1903.

Photograph. H. J. Lutcher Stark Center for Physical Culture \& Sport.

The University of Texas, Austin. 
For the Defense

$\theta$ 
